\title{
Commercial harvests of saltwater crocodile Crocodylus porosus eggs by Indigenous people in northern Australia: lessons for long-term viability and management
}

\author{
B. Corey, G.J.W Webi, S.C. Manolis, A. Fordham, B.J. Austin, Y. Fukuda \\ D. NICHOLLS and K. SAALFELD
}

\begin{abstract}
Sustainable commercial use of native wildlife is an alternative economic means of land use by Indigenous people in remote rural areas. This situation applies within large tracts of land owned by Indigenous people across northern Australia. The commercial use of saltwater crocodiles Crocodylus porosus is a growing industry in Australia's Northern Territory. Although Indigenous people sell crocodile eggs and hatchlings, the majority of harvesting and incubation is done by non-indigenous people from less remote areas. One Indigenous community has been heavily involved in this industry and now manages its own harvest and incubation programme. We present a case study of this programme, which has transitioned from outside agencies managing the harvest, to complete local ownership and management. Egg harvests and incubation success rates declined by $40 \%$ following the switch to local management. Income increased, as did production costs; in particular, royalty payments made to Indigenous landowners. The declines reflect the community's motives for engaging in the industry, which have been socially rather than commercially driven, and damage to nesting habitat by feral animals. The increase in royalties reflects the need to compete with non-indigenous harvesters from outside the township, who are strictly commercially driven. Harvesting, incubation and trade in crocodile eggs and hatchlings can form a viable and sustainable enterprise for remote Indigenous
\end{abstract}

B. CoReY* (Corresponding author) and D. Nicholls Bawinanga Aboriginal Corporation, PMB 102 Winnellie, Northern Territory, 0822, Australia

Email ben.corey@dpaw.wa.gov.au

G. J. W. WebB $\dagger$ and S. C. Manolis Wildlife Management International Pty Limited, Karama, Northern Territory, Australia

A. Fordham Centre for Aboriginal Economic Policy Research, College of Arts and Social Sciences, The Australian National University, Australian Capital Territory, Australia

B. J. Austin Research Institute for the Environment and Livelihoods, Charles Darwin University, Northern Territory, Australia

Y. FuKuda and K. SAalfeld Northern Territory Department of Environment and Natural Resources, Northern Territory, Australia

${ }^{\star}$ Current address: Department of Parks and Wildlife, PO Box 942, Kununurra, Western Australia, 6743, Australia

$\dagger$ Also at: Research Institute for the Environment and Livelihoods, Charles Darwin University, Northern Territory, Australia

Received 11 December 2016. Revision requested 4 January 2017.

Accepted 23 January 2017. First published online 13 June 2017. communities. However, efficiency needs to be improved to fulfil the need for a reliable and dependable supply chain, and regulatory institutions should give Indigenous harvesters sufficient freedom to pursue innovative and viable livelihood options.

Keywords Australia, Crocodylus porosus, economic development, natural resources, saltwater crocodile, sustainable livelihoods, sustainable use, wildlife utilization

\section{Introduction}

Tndigenous people have depended on wildlife harvesting for millennia, with hunting and gathering occupying a central place in culture and the structure of society. Accordingly, efforts to promote sustainable economic development on remote Indigenous-owned lands have often focused on wildlife resources, with products increasingly entering a market-based cash economy rather than being distributed according to traditional practices (Altman \& Cochrane, 2005). However, exploitation driven by market demand, in the absence of appropriate management, can increase the risk of decline and extinction of wildlife populations (Sodhi et al., 2004; Wilson et al., 2010; Eisemberg et al., 2011). The Convention on International Trade in Endangered Species of Wild Fauna and Flora (CITES) was enacted specifically to counter threats of species extinction linked directly to international trade in wildlife.

There is an increasing body of evidence (e.g. Gordon \& Ayiemba, 2003; Lichtenstein, 2010; Cooney et al., 2015), now entrenched in conservation paradigms (e.g. Convention on Biological Diversity, 2004; IUCN, 2004), that the commercial use of wildlife can and should be a means for improving rural livelihoods. The sustainable use of wildlife resources that exploit the same productive potential of land normally used for agriculture or pastoralism can be a building block for both sustainable economic development and conservation (Lindsey et al., 2013). This form of resource use values and depends on maintaining, rather than replacing, native wildlife and its environment (Child, 1996; Hutton \& Leader-Williams, 2003; Cooney, 2008).

In the Northern Territory of Australia (Fig. 1) $81 \%$ of the Indigenous population live in remote areas and own nearly 


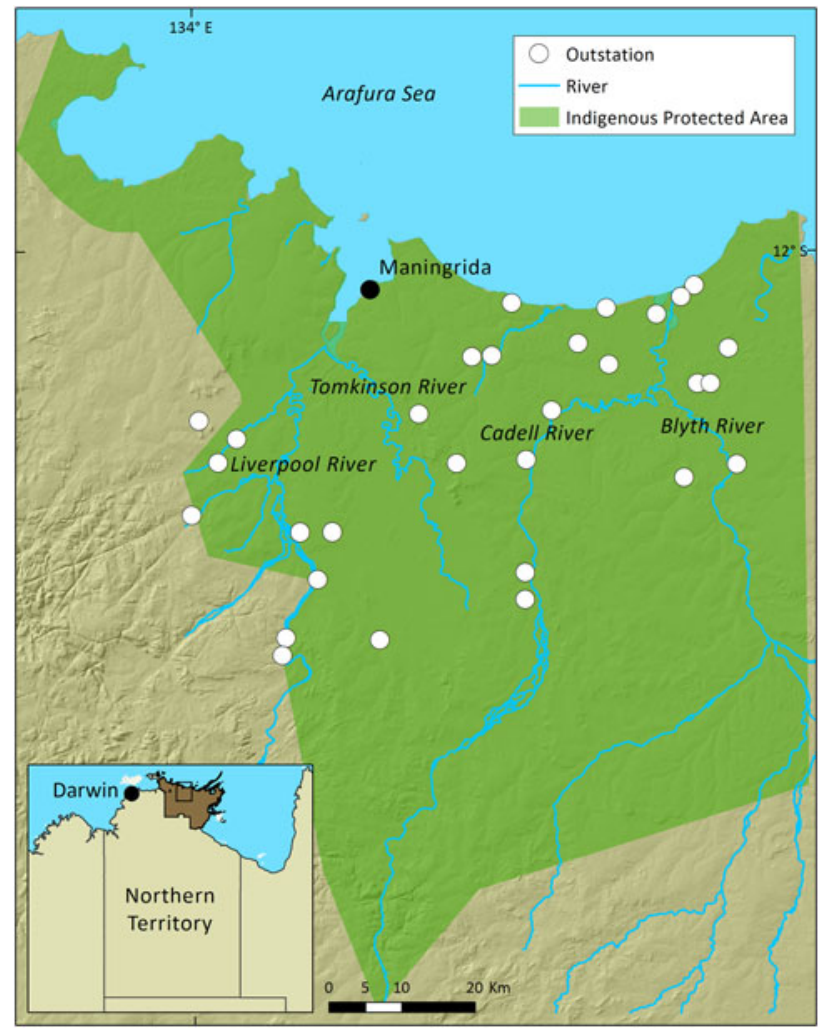

FIG. 1 The locally managed Indigenous Protected Area in the Maningrida region of the Northern Territory, Australia, with the major river systems where Crocodylus porosus eggs have been harvested, and the locations of outstations occupied by Indigenous people. The dark shaded area on the inset map is Arnhem Land.

half of the land mass, mainly under communal title (Altman et al., 2007). The relatively harsh environment limits the potential for crop production and grazing livestock as a means of Indigenous people participating in the market economy. Viable arts industries (e.g. Koenig et al., 2011) and community ranger (land and sea management) programmes (e.g. Gorman \& Vemuri, 2012) have been established, and payments for environmental services are also emerging (e.g. Russell-Smith et al., 2013). Nevertheless, options for economic development in remote areas are constrained by limited infrastructure, distance from economic centres, low levels of literacy and numeracy, poor health, limited engagement with the private sector, the inalienable conditions of communal land title, and the need for arrangements about resource use to be approved by Land Councils established under the Aboriginal Land Rights (Northern Territory) Act 1976 (Taylor, 2003; Gorman et al., 2008a). Limited economic development means that many Indigenous people living in these areas depend on welfare-related programmes, plus subsistence harvesting of wildlife to supplement income.

Indigenous-owned lands and waterways in the Northern Territory have been largely unaffected by development and retain much of their original biodiversity (Altman et al.,
2007). Large tracts of these lands have been incorporated into Australia's National Reserve System as Indigenous Protected Areas (Davies et al., 2013), and are generally managed under IUCN Category VI as protected areas with sustainable use of natural resources. This seems an appropriate option for the Indigenous estate, with economic benefits being derived in ways that connect people to country and customary wildlife harvesting practices (Webb et al., 1996; Altman \& Cochrane, 2005; Cooney \& Edwards, 2009). Such enterprises, linking income to land management, provide incentives to maintain natural habitats, and localized mechanisms to mobilize attention, energy and resources for monitoring, management and threat control (Webb, 2002), and result in the generation of new management knowledge and capacity (Cooney, 2008).

To this end, the Indigenous-owned and managed Bawinanga Aboriginal Corporation has incorporated sustainable use programmes involving freshwater turtles Chelodina rugosa (Fordham et al., 2007), native plants (Gorman et al., 2008b) and saltwater crocodiles Crocodylus porosus (Austin \& Corey, 2012) into the local hybrid economy (Altman \& Cochrane, 2005). The crocodile programme in Maningrida, which is the focus of this study, involves harvesting and incubating crocodile eggs, and selling hatchlings to commercial crocodile farms. The continuation of this enterprise over 26 years stands in stark contrast to the long history of failure of commercial enterprises on Indigenous-owned lands in Australia (Dale, 1996).

Despite the longevity of Bawinanga Aboriginal Corporation's programme and the factors that have contributed to its comparative success (Fordham et al., 2010; Austin \& Corey, 2012), this enterprise has not reached its full potential (Fordham et al., 2010). We provide a critical assessment of the programme, in a case study of how an Indigenous community without a traditional cash economy has adapted to the challenges involved. We track the evolution of the programme over time, and the transition from outside agencies managing the harvest to local ownership and management. Specifically, we compare harvest records between the two periods of management, and highlight lessons learnt from the analyses of both the harvest data and management processes, as well as the personal involvement of the authors in various aspects of the harvest over time.

\section{Case study}

\section{Saltwater crocodiles}

Saltwater crocodile populations were depleted to c. 3,00o individuals in the Northern Territory by unmanaged commercial exploitation during 1945-1971, but following their protection in 1971 they entered a recovery phase, which is now almost complete. The Northern Territory population 
is estimated to include $80,000-100,000$ non-hatchlings (Fukuda et al., 2011). The Australian population of saltwater crocodiles was originally listed on Appendix II of CITES in 1975, transferred to Appendix I in 1979, and then transferred back to Appendix II in 1985 specifically to facilitate international trade based on ranching (CITES, 2017). Ranching refers to the collection of wild eggs, hatchlings and/or juveniles, which have a low probability of surviving to adulthood, and growing them in captivity. Saltwater crocodiles are $>5 \mathrm{~m}$ in length and are predators of both people and livestock in the Northern Territory (Fukuda et al., 2014). Commercial sustainable use programmes were introduced in the early 1980 os to provide incentives to conserve crocodile nesting habitat and to generate economic benefits for rural landowners, to help compensate for the increased problems the recovering crocodile populations were causing (e.g. stock losses).

\section{Harvest programme}

The Northern Territory ranching programme involves commercial harvesting of eggs, with landowners being paid AUD 20-40 for each live egg (containing a viable embryo), depending on location and collection costs. Up to 70,000 eggs are harvested per year (Leach et al., 2009) and c. $70 \%$ of these come from Indigenous-owned lands (Northern Land Council, 2011). With the exception of the Bawinanga Aboriginal Corporation, involvement of Indigenous people has been largely passive, and confined to the acceptance of royalties for harvested eggs. Although the crocodile farming industry in the Northern Territory has grown and become more technically advanced and viable, contributing c. AUD 25 million to the economy annually (Department of Business, 2015), commercial viability had previously been constrained by a series of technical inefficiencies (e.g. Isberg et al., 2009).

\section{Regulatory context}

Northern Land Council The Aboriginal Land Rights (Northern Territory) Act 1976 provides the basis on which Aboriginal people in the Northern Territory can claim rights to lands based on traditional occupation. Land is then granted under inalienable freehold title; it cannot be bought, acquired or mortgaged. The Act invests power in Land Councils (in this case the Northern Land Council) to ensure that Aboriginal landowners have given informed consent for any commercial activity to take place on their lands. Specifically, section 19 of the Act requires that Land Use Agreements be signed by business proponents and relevant Indigenous landowners, detailing the activities to take place and the benefits (usually royalties) that landowners will receive. This process of consultation requires a lawyer, anthropologist and biologist, as well as other staff who manage the administrative aspects of any contractual agreements. The Northern Land Council has the power to influence the nature and extent of benefits received by landowners through participation in the market economy.

Northern Territory Parks and Wildlife The saltwater crocodile is protected under the Territory Parks and Wildlife Conservation Act. Section 66 of this Act makes it illegal to harvest crocodiles or their eggs without securing a permit; these are issued under a management plan, and population monitoring also occurs as part of the harvest programme (Leach et al., 2009). Under this Act, Indigenous people have rights to harvest wildlife for subsistence purposes without a permit, but this does not extend to commercial sales of wildlife. Indigenous people are not bound by hunting regulations or seasons when taking wildlife for food or other traditional purposes.

\section{Maningrida}

Maningrida is located on the north-central coast of Arnhem Land, c. $550 \mathrm{~km}$ from the regional capital of Darwin (Fig. 1). Arnhem Land is a c. 94,000 km² Aboriginal Reserve (Fig. 1), with restricted access by non-indigenous people. Access to Aboriginal lands in the northern region of the Northern Territory is managed by the Northern Land Council, which, in addition to the responsibilities mentioned above, is also tasked with helping Aboriginal people to acquire and manage their traditional lands and seas (NLC, 2011). Maningrida was established in 1957 as a service and trading station. It comprises an administrative region of c. $10,000 \mathrm{~km}^{2}$, with a current population of c. 2,650 (mostly Indigenous people). More than half of this land $\left(6,732 \mathrm{~km}^{2}\right)$ lies within the Djelk Indigenous Protected Area (Ansell \& Koenig, 2011; Fig. 1). Another 360 Indigenous people live semi-permanently in 32 outstations in the region (Fig. 1), mostly in family-based communities of 10-50 people. Maningrida is in the wet-dry tropics of northern Australia, where $>90 \%$ of the mean annual rainfall $(1,284 \mathrm{~mm})$ falls in the wet season, during December-April.

The Bawinanga Aboriginal Corporation was established in 1979 as a resource agency for Indigenous people in the region. It is responsible for the provision of various community services and enterprises, one of which is the Djelk ranger programme (Altman \& Cochrane, 2005; Ansell \& Koenig, 2011). Although the Corporation has no legislative powers or statutory responsibilities under the Aboriginal Land Rights (Northern Territory) Act 1976, it has played an important role in advocating for land rights, outstation development and regional Aboriginal self-determination for $>100$ land-owning groups in the Maningrida region (Fig. 1). It is governed by a board of annually elected 
TABLE 1 Royalty payment rates and hatchling values for Crocodylus porosus eggs harvested from the Maningrida region in the Northern Territory of Australia (Fig. 1) by Wildlife Management International (WMI) and the Bawinanga Aboriginal Corporation (BAC) during 1989-2015.

\begin{tabular}{|c|c|c|c|c|c|c|}
\hline Season & Harvester & Incubator & Royalty paid on & $\begin{array}{l}\text { Royalty rate } \\
\text { (AUD) }\end{array}$ & $\begin{array}{l}\text { Hatchling value } \\
\text { (AUD) }\end{array}$ & $\begin{array}{l}\text { Royalty } \\
\text { distributor }\end{array}$ \\
\hline 1989-1990 & WMI & WMI & All eggs harvested & 3 & Not applicable & $\mathrm{BAC}$ \\
\hline 1990-1991 & WMI & WMI & All live eggs harvested & 5 & Not applicable & BAC \\
\hline 1991-1992 & WMI & WMI & All live eggs harvested & 5 & Not applicable & $\mathrm{BAC}$ \\
\hline 1992-1993 & WMI & WMI & All live eggs harvested & 5 & Not applicable & $\mathrm{BAC}$ \\
\hline 1993-1994 & WMI & WMI & All live eggs harvested & 5 & Not applicable & $\mathrm{BAC}$ \\
\hline 1994-1995 & WMI & WMI & All live eggs harvested & 5 & Not applicable & BAC \\
\hline 1995-1996 & WMI & WMI & All live eggs harvested & 5 & Not applicable & BAC \\
\hline 1996-1997 & WMI & $\mathrm{BAC}$ & All live eggs harvested & 5 & Not applicable & BAC \\
\hline 1997-1998 & $\mathrm{BAC}$ & BAC & Each viable hatchling sold & 5 & 30 & BAC \\
\hline 1998-1999 & BAC & BAC & Each viable hatchling sold & 5 & 30 & BAC \\
\hline 1999-2000 & $\mathrm{BAC}$ & $\mathrm{BAC}$ & Each viable hatchling sold & 8 & 30 & $\mathrm{BAC}$ \\
\hline 2000-2001 & $\mathrm{BAC}$ & $\mathrm{BAC}$ & Each viable hatchling sold & 8 & 35 & $\mathrm{BAC}$ \\
\hline 2001-2002 & $\mathrm{BAC}$ & $\mathrm{BAC}$ & Each viable hatchling sold & 8 & 37.50 & $\mathrm{BAC}$ \\
\hline 2002-2003 & BAC & BAC & Each viable hatchling sold & 10 & 37.50 & BAC \\
\hline 2003-2004 & BAC & BAC & Each viable hatchling sold & 10 & 37.50 & BAC \\
\hline 2004-2005 & BAC & BAC & Each viable hatchling sold & 10 & 40 & BAC \\
\hline 2005-2006 & BAC & BAC & Each viable hatchling sold & 10 & 40 & BAC \\
\hline 2006-2007 & BAC & BAC & Each viable hatchling sold & 15 & 45 & BAC \\
\hline \multicolumn{7}{|l|}{$2007-2008^{2}$} \\
\hline $2008-2009^{3}$ & BAC & BAC & $50 \%$ of each viable hatchling sold & 30 & 60 & NLC \\
\hline 2009-2010 & BAC & BAC & $50 \%$ of each viable hatchling sold & 30 & 60 & NLC \\
\hline 2010-2011 & $\mathrm{BAC}$ & $\mathrm{BAC}$ & $40 \%$ of each viable hatchling sold & 18 & 45 & NLC \\
\hline 2011-2012 & $\mathrm{BAC}$ & $\mathrm{BAC}$ & $40 \%$ of each viable hatchling sold & 18 & 45 & NLC \\
\hline 2012-2013 & BAC & BAC & $40 \%$ of each viable hatchling sold & 18 & 45 & NLC \\
\hline 2013-2014 & $\mathrm{BAC}$ & $\mathrm{BAC}$ & $40 \%$ of each viable hatchling sold & 18 & 45 & NLC \\
\hline 2014-2015 & $\mathrm{BAC}$ & $\mathrm{BAC}$ & $40 \%$ of each viable hatchling sold & 18 & 45 & NLC \\
\hline
\end{tabular}

${ }^{1}$ NLC, Northern Land Council.

${ }^{2}$ Harvesting did not take place during the 2007-2008 wet season because of a moratorium imposed on egg harvests by the Northern Land Council, a regional regulatory body responsible for commercial activity on Aboriginal-owned land.

${ }^{3}$ Since 2008-2009, Land Use Agreements, which are legally binding contracts between Indigenous or non-indigenous harvesters and Indigenous landowners on whose land the eggs are harvested (that stipulate the payment of royalties and/or other benefits), have been required by the Northern Land Council.

Indigenous members from across these groups. Land ownership is still based on traditional law, in which a system of managers and owners exists. Land managers have maternal links to land, whereas landowners have paternal links to land. Thus, all Indigenous people in the region are landowners and are involved in decision making processes that affect their lands.

Indigenous people in Maningrida were involved in a wide-ranging research programme on $C$. porosus during the 1970 os and 1980s (e.g. Messel et al., 1981). When the Northern Territory Government initiated the crocodile egg harvest programme in 1989 (Table 1), it was implemented on the Government's behalf by Wildlife Management International Pty Limited. The Bawinanga Aboriginal Corporation and various rangers were closely involved with the harvest, assisting with the collection of eggs and the distribution of payments (royalties) to local Indigenous landowners. When this programme was privatized, Wildlife Management International continued the harvest with assistance from the Bawinanga Aboriginal Corporation, on behalf of the crocodile farms. Wildlife Management International then assisted in the transfer of harvesting and incubation responsibility to the Bawinanga Aboriginal Corporation in 1997 (Table 1), helping to construct an incubator on site, providing technical advice and training, and initially selling hatchlings produced by the Corporation to crocodile farms.

\section{Egg location, collection, incubation and royalty payments}

Crocodiles nest during the wet season in freshwater swamps and along tidal river banks, laying c. 50 eggs per nest (Webb et al., 1977). There are four river systems in the Maningrida region (Blyth, Cadell, Liverpool and Tomkinson Rivers; Fig. 1), where the majority of egg harvesting occurs. Eggs are harvested from an outboard-powered aluminium dingy, or harvesters are dropped into freshwater swamps by a helicopter. Eggs are then transported to facilities in 
Maningrida, cleaned, and assessed (for fertility and viability) against criteria outlined in Webb et al. (1987). Eggs are incubated at a constant temperature of $32^{\circ} \mathrm{C}$, and $\geq 99 \%$ humidity.

The Bawinanga Aboriginal Corporation typically receives a quota of 2,700-3,000 eggs per year. All egg harvesters across the Northern Territory are allocated annual quotas under the Northern Territory Government management programme, which currently has a harvest ceiling of 70,000 eggs per year (Leach et al., 2009). The criteria used to allocate harvest quotas are outlined in the current management plan. The Corporation pays royalties (usage-based payments) to the relevant Indigenous landowners for any eggs collected (or hatchlings produced from eggs) from their lands.

\section{Compilation of harvest records, income and operational costs}

We compiled a chronological history of the harvest (Table 1) during 1989-1997 (when Wildlife Management International managed egg harvests) and 1998-2015 (when the Bawinanga Aboriginal Corporation managed egg harvests), using records of harvested eggs and payments for eggs and hatchlings, from the Bawinanga Aboriginal Corporation, Wildlife Management International and the Northern Territory Government. In 1996-1997 Wildlife Management International harvested eggs and the Bawinanga Aboriginal Corporation incubated them. Harvest data were assigned to the four major river systems in the Maningrida area, with occasional harvests outside those areas by both the Bawinanga Aboriginal Corporation and Wildlife Management International grouped as 'other'.

Because the classification of eggs for harvest quota purposes has changed over time and the Bawinanga Aboriginal Corporation's records were sometimes incomplete, we based all comparisons between the Bawinanga Aboriginal Corporation and Wildlife Management International on a combination of the most complete data across their respective years of management and criteria defined by Leach et al. (2009): (1) the number of live eggs harvested (those containing a viable embryo and placed into an incubator); (2) the number of normal hatchlings produced (i.e. no deformities); and (3) incubation success rates, which are based on the number of normal hatchlings produced, as a proportion of the number of live eggs incubated.

Detailed operational costs were not available for the entire period of egg harvesting by the Bawinanga Aboriginal Corporation. However, we were able to compile financial records from 2009-2012, when one of the authors (BC) was employed by the Corporation. These included staff costs (wages for harvesting, incubation, egg husbandry, permit compliance, reporting), helicopter hire, incubation costs (power, water), fuel and other costs (equipment, freight).

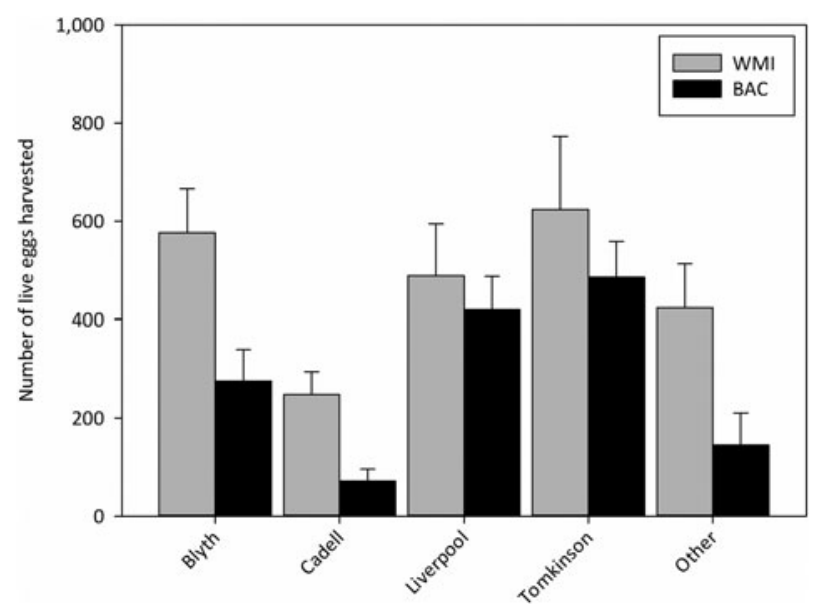

FIg. 2 The mean (+SE) number of live Crocodylus porosus eggs harvested from rivers in the Maningrida region (Fig. 1) by Wildlife Management International (WMI) during 1989-1997 and by the Bawinanga Aboriginal Corporation (BAC) during 1997-2015.

\section{Results}

\section{Egg harvests}

Egg harvests differed between the two periods of management and between river systems (two-way ANOVA: harvester: $F_{1,110}=14.678, \mathrm{P}<0.001 ;$ system: $F_{4,110}=7.589$, $\mathrm{P}<0.001$; harvester $\times$ system: $F_{4,110}=0.742, \mathrm{P}=0.566$; Figs 2 \& 3a). Wildlife Management International harvested a mean of 2,359 eggs per season (range $=1,272-4,748$; Fig. 3a), the majority of which came from the Tomkinson (26.4\%), Blyth (22.7\%) and Liverpool (20.0\%) rivers (Fig. 2). In comparison, the Bawinanga Aboriginal Corporation harvested a mean of 1,416 eggs per season (range $=269-2,287$; Fig. 3a), which came predominately from the Tomkinson (35.8\%), Liverpool (29.4\%) and Blyth (20.5\%) rivers (Fig. 2). The Cadell River, which is a smaller river, contributed fewer eggs to overall harvests, particularly in the Bawinanga Aboriginal Corporation-managed years (Fig. 2).

There was an overall harvest limit for the Northern Territory but no area-specific quotas were in place for the period when Wildlife Management International managed egg harvests at Maningrida. The overall limit (harvest ceiling) was based on the stock needed for the farms, and for exploring the impacts of harvesting on populations, which were found to be negligible (Webb \& Manolis, 1992). Area-specific quotas were then introduced as an administrative tool aimed at exceeding harvest levels, rather than as biologically derived quotas calculated to match sustainability requirements. During 1997-2015 the Bawinanga Aboriginal Corporation harvested $57.8 \%$ of its allocated annual quota and did not once meet its quota; in only one season did harvests approach the quota (88.3\% in 2001-2002; Fig. 3a), and in some years harvests failed to meet even $50 \%$ of the quota (Fig. $3 \mathrm{a}$ ). 

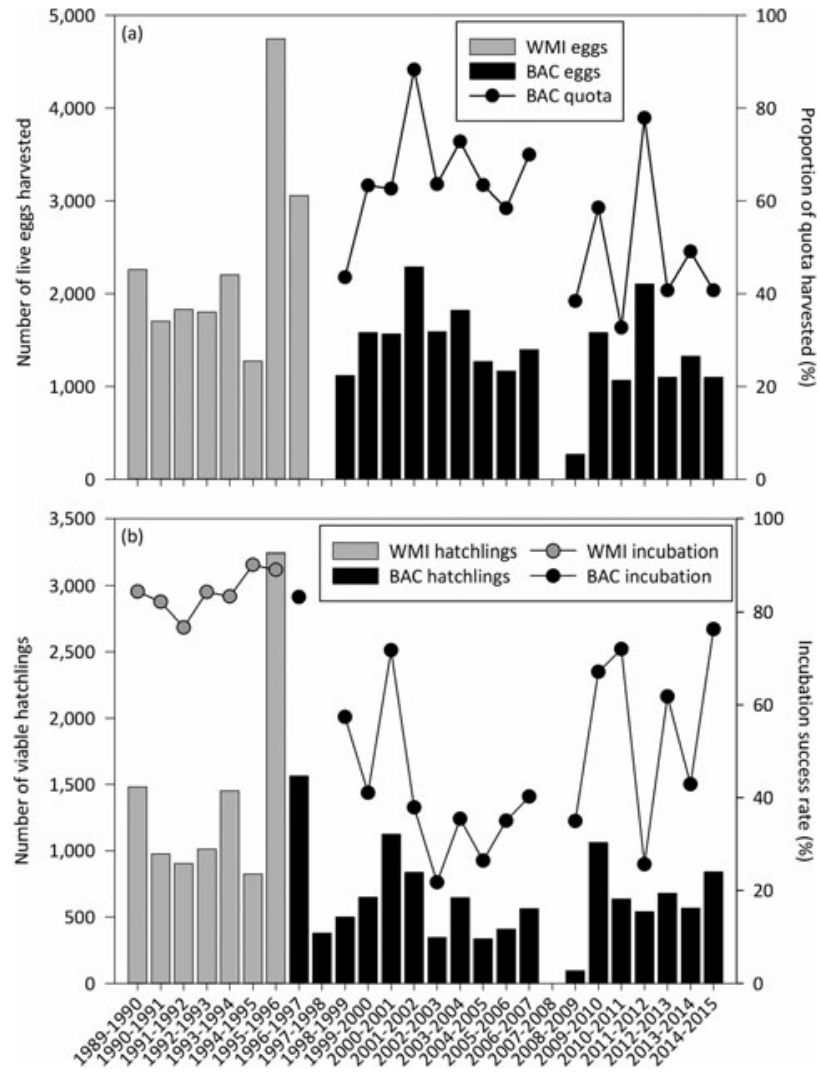

FIG. 3 (a) The total number of live Crocodylus porosus eggs harvested from the Maningrida region (Fig. 1) by Wildlife Management International (WMI) and the Bawinanga Aboriginal Corporation (BAC) (bars), and the number of eggs harvested as a proportion of government-allocated harvest quotas (dots/line). Note that quotas were not in place when WMI harvested. (b) The number of viable C. porosus hatchlings produced by WMI and BAC (bars), and the hatching success rate of incubated eggs (dots/line). In 1996-1997 eggs were harvested by WMI but were incubated by BAC, and there was no harvest in 2007-2008.

\section{Egg incubation}

Wildlife Management International achieved higher incubation success rates than the Bawinanga Aboriginal Corporation (Kruskal-Wallis one-way ANOVA on ranks: $H_{1}=13.018, \quad \mathrm{P}<0.001$; Fig. 3b). Wildlife Management International produced a mean of 1,413 normal hatchlings from 1,659 live eggs (mean success rate $=84.3 \%$ ), whereas the Bawinanga Aboriginal Corporation produced a mean of 654 hatchlings from 1,396 eggs (mean success rate $=48.9 \%$; Fig. 3b).

\section{Income and royalties}

When Wildlife Management International carried out the harvest for the Northern Territory Government, the Government initially paid landowners AUD 3 per egg

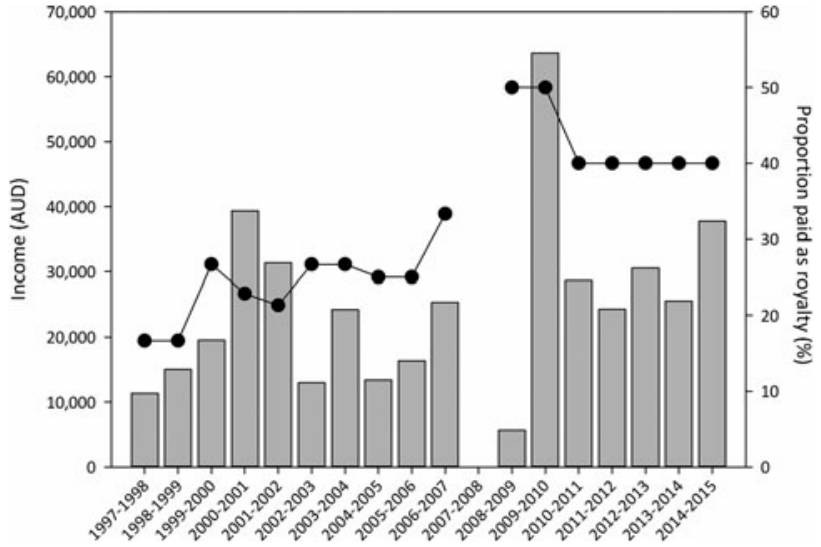

FIG. 4 Gross annual income from Crocodylus porosus hatchling sales by the Bawinanga Aboriginal Corporation (bars) and the proportion of this income paid to landowners as a royalty (dots/ line). There was no harvest in 2007-2008.

found (all eggs, live or dead), and then AUD 5 per live egg harvested (Table 1); this amounted to a mean of AUD 11,232 (range $=$ AUD 6,360-23,740) in royalties per season, and a total of AUD 89,859. The Bawinanga Aboriginal Corporation received a mean annual income of AUD 24,990 from hatchling sales (range $=$ AUD 5,640-63,66o; Fig. 4). The royalty rate changed several times during the years when the harvest was managed by the Corporation (Table 1) but was based on the number of hatchlings sold rather than the number of live eggs harvested. The Corporation paid a mean of AUD 8,495 (range = AUD $1,890-31,830)$ in royalties, which amounted to $17-50 \%$ of the total sale price of hatchlings (Table 1; Fig. 4). During 1989-2007 the Corporation distributed royalty payments directly to landowners; from 2008 , these payments were made to the Northern Land Council, which distributed them to landowners (Table 1). Since 1989 egg harvesting has contributed a total of AUD 514,692 to Maningrida's economy.

\section{Operational costs and economic viability}

Until 2008 the Bawinanga Aboriginal Corporation owned and operated its own helicopter. The helicopter operating costs were unavailable, but the use of the helicopter was subsidized by other programmes within the Corporation. During 2009-2012 the Corporation hired a helicopter at a rate of AUD 790 per hour, for a mean of 23 hours per season (range $=11-44$ hours), at a mean cost of AUD 18,170 per year.

When staffing costs (wages for harvesting, incubation, egg husbandry, permit compliance, reporting), helicopter charters, incubation (power, water), fuel and other costs (equipment, freight) are averaged across this period, the total cost of hatchling production, plus an arbitrary buffer of $8 \%$, amounts to AUD 40,000 per season, or just over 
AUD 26 per live egg. This amount does not include royalties because these are not fixed, but they are currently set at $40 \%$ of the sale price of each hatchling (Table 1). Thus, the true total cost was AUD 40,000 (harvesting and incubation costs) + AUD 27,617 (royalty costs) $=$ AUD 67,617. At current hatchling prices (AUD 45) the Corporation would need to harvest at least $70 \%$ of its 2,700 egg quota $(1,900$ eggs) and successfully incubate $80-85 \%$ of these to cover costs and royalties. At present this is not occurring.

\section{Discussion}

Our case study demonstrates that community-managed wildlife use programmes can yield conservation benefits and improvements in rural Indigenous livelihoods (Gordon \& Ayiemba, 2003; Lichtenstein, 2010; Cooney et al., 2015). Crocodile abundance at Maningrida has been increasing despite 26 years of egg harvests (Fukuda et al., 2011), confirming that egg harvests are well within sustainable levels. Public tolerance of the increasing crocodile population in the Northern Territory is partly based on its established economic value (DoB, 2015). The programme has been worth over half a million dollars to the local economy, which is significant in the context of Maningrida's very small economy (Northern Territory Government, 2009), with limited options for expansion. It has created employment opportunities that utilize local people's skills in wildlife harvesting (Webb et al., 1996; Altman \& Cochrane, 2005). This is one of the longest running Indigenousmanaged wildlife enterprises in a remote part of Australia. In strict business terms, however, its economic viability appears to be marginal. Perhaps of most concern is the fact that the Northern Land Council, which has responsibility for helping Indigenous Australians to acquire and manage their traditional lands, may be stifling economic development, through unnecessary bureaucracy and administration. Strategies for promoting growth in ways that continue to benefit the local economy and environment are timely.

\section{Egg harvests}

Harvests have declined (Figs 2 \& 3 a), but not as a consequence of reduced population abundance; monitoring confirms that crocodile populations are still increasing, both locally and across the Northern Territory (Fukuda et al., 2011). Despite widespread harvesting of eggs, population abundance has increased, notwithstanding a concurrent increase in the total egg harvesting quota across the entire Northern Territory (Leach et al., 2009). Despite a long history of consumptive use of both crocodiles and their eggs, and traditional knowledge associated with exploiting these resources (Webb et al., 1996), a shift from a solely subsistence-based harvest to a cash-based economy has not translated into increased harvesting pressure, nor threatened the persistence of the exploited species, as has occurred in other parts of the world (e.g. Robinson \& Bennett, 2002; Sodhi et al., 2004; Eisemberg et al., 2011). In this case, cash has not provided an incentive to over-harvest, or even to maximize the permitted harvest.

\section{Egg incubation}

The Bawinanga Aboriginal Corporation's incubation success rates were poor (Fig. 3b) and below those of Wildlife Management International, which are generally accepted as the industry standard, despite using the same incubation methods. In our experience, locally employed people involved in egg harvesting at Maningrida find the harvesting aspect of the enterprise exciting, whereas egg incubation is seen as more mundane, and eggs can die if suitably qualified staff are not on hand to monitor them daily. Incubation is an equally important aspect of the enterprise, as it provides the opportunity to turn the investment of harvesting into income through hatchling sales. The improvement in incubation success rates in 2009-2010 (Fig. 3 b) can be attributed to an increased focus on staff training, which was provided by Wildlife Management International. The decline again in 2011-2012 suggests that training in egg husbandry and incubation should be an ongoing process. Incubation success rates did not improve during 2013-2015, when half of the Bawinanga Aboriginal Corporation's eggs were incubated by a commercial operator (not Wildlife Management International) in Darwin (Fig. 3b).

Income, royalties, operational costs and economic viability

Income from egg harvesting has increased in recent years (Fig. 4), as a result of an increase in hatchling values (Table 1), as have operational costs such as royalties and helicopter hire (Table 1; Fig. 4). It is difficult to gauge how these operational costs compare with those of other Indigenous-managed wildlife harvesting enterprises in Australia because there are so few, and such figures are not readily available. However, business costs are higher in remote Indigenous communities (Biddle et al., 2008). Based on mean harvest figures (1,416 live eggs) and incubation success rates $(47.2 \%)$, and factoring in both operating costs and royalties, the enterprise at Maningrida has not operated in a commercially viable way.

So why does the Bawinanga Aboriginal Corporation continue to harvest? Crocodile egg harvesting by the Corporation was initially not profit driven, but rather socially and environmentally driven (Austin \& Corey, 2012). It was seen as a way to engage people in work that utilized existing skills 
in wildlife harvesting (Webb et al., 1996), and financed threat reduction for crocodile habitat. For this reason the benefits go well beyond the purely economic, to strengthening and utilizing Indigenous knowledge and skills, building community capacity for natural resource management, keeping people on country (i.e. enabling them to continue to live on their traditional estates), ensuring local ownership and management of wildlife resources, and improving people's physical and mental health (Burgess et al., 2009; Cooney \& Edwards, 2009; Garnett et al., 2009). These less tangible benefits may outweigh the direct financial benefits to Indigenous communities (Austin \& Garnett, 2011). Nevertheless, the harvest data suggest that the egg resource is sufficient and accessible (Fig. 3a) and the Corporation's data suggest it has the capacity to produce enough hatchlings (Fig. 3b). Thus, one of the key factors in ensuring economic viability could simply be consistency in supply.

\section{Underutilization of quotas}

Several interrelated factors may account for the reduction in egg harvests and the underutilization of harvest quotas. These include seasonality, bureaucracy, feral animals and various social and cultural factors. For instance, aboveaverage rainfall and widespread flooding prior to harvests led to the loss of nests in both 1998-1999 and 2010-2011. Seasonality is not a constraint, as all egg harvesters across the Northern Territory have to deal with this, and can schedule harvests accordingly. However, seasonality coupled with the bureaucratic hurdles of drawn-out consultations with landowners, facilitated by the Northern Land Council, followed by lengthy delays in finalizing Land Use Agreements, may mean that opportunities to begin harvesting prior to seasonal events such as flooding may be lost. Such was the case in 2009-2010 and again in 2010-2011. One option for remedying this situation may be to revisit the requirements of implementing section 19 of the Aboriginal Land Rights (Northern Territory) Act 1976; perhaps through establishing a streamlined process for (relatively) small-scale enterprises such as these (Cooney \& Edwards, 2009). However, in lieu of an overhaul of legislation and policy, the Northern Land Council must be better resourced to perform its important function of supporting Indigenous economic development.

In the Blyth and Cadell River systems, where the decrease in harvests has been most pronounced (Fig. 2), invasive buffalo Bubalus bubalis and pigs Sus scrofa may be implicated in reducing the abundance of suitable nesting habitat. Damage to nesting habitat from both species is obvious and extensive (B. Corey, unpubl. data) and buffalo densities are high (Saalfeld, 2014). Pigs have also caused the extirpation of freshwater turtles and degradation of freshwater habitats in both these river systems (Fordham et al., 2006, 2008). Although numbers of non-hatchling crocodiles continue to increase (Fukuda et al., 2011), the long-term impacts of reductions in nesting remain unclear. Feral animals are a management paradox because despite the environmental damage they cause, they form part of the diet of people inhabiting the region (Fordham et al., 2006), and are a source of income from royalties for safari hunting (Brook et al., 2006) and mustering (Austin \& Garnett, 2011). Serious consideration will need to be given to the management of these species if severe and lasting damage to ecosystem function, not just crocodile nesting habitat, is to be averted.

In remote Indigenous communities, attitudes and priorities associated with employment, and its largely economic justifications, can be different to non-remote communities. People use much of their labour to produce social capital as opposed to financial reward (McRae-Williams \& Gerritsen, 2010), with the maintenance of kinship and other relations being critical. Poor health and education, and a legacy of government policies that, in hindsight, have been inappropriate (Altman, 2000; Maru \& Davies, 2011) are also implicated in the dichotomy of attitudes to work between remote and non-remote communities.

The social factors that drive species declines and extinctions as a result of over-harvesting, such as extreme poverty, population size, food supply and traditional medicines (e.g. Robinson \& Bennett, 2002; Sodhi et al., 2004; Eisemberg et al., 2011) are absent in Maningrida because of welfare payments (Biddle et al., 2008; NTG, 2009) and a low human population density (Altman et al., 2007). Additionally, egg harvesters in Maningrida are employed as rangers, often with competing workplace commitments because of their core focus of managing fire and invasive species (Fordham et al., 2010). The interaction of these factors means that sometimes less emphasis may be placed on crocodile egg harvesting as a means to make money (Davies et al., 1999). However, cash flow is fundamental to sustaining and improving the viability of the enterprise.

\section{Constraints on enterprise development and challenges for the future}

The crocodile farming industry, which provides the market for eggs and hatchlings, has itself been evolving. When harvests were introduced it was a fledgling industry with marginal commercial viability. The demand for eggs and hatchlings fluctuated from year to year and in some years the farm capacity was met so easily that the Bawinanga Aboriginal Corporation had to sell hatchlings to farms outside the Northern Territory. The industry is now more refined, with established markets and contractual obligations to supply skins, which is not compatible with the historical variation in the Corporation's production (Fig. 3a,b). Adapting to the new market demand for a more dependable supply chain is a challenge the Corporation must meet.

Another challenge for the Corporation is maintaining an enterprise that is both economically and culturally viable; 
one that facilitates local residents to utilize their existing skills and maintain the ability to manage their land and wildlife resources. This may not be easy given the high costs of production, and in particular the high royalties (Fig. 4). These result directly from the Corporation, an Indigenous enterprise, needing to compete with outside business organizations that are not constrained by the complexities of operating an Indigenous business on remote traditional Aboriginal estates. For instance, locally employed people are bound by strict cultural protocols governing who can harvest in particular areas, and sometimes areas may be closed for ceremonial purposes (Austin \& Corey, 2012).

Higher royalties may initially appear to be good for landowners but the benefits stop there. Outside organizations can pay high royalties because they provide little employment or training to local people, and their contribution to the local economy is limited; staff, equipment and fuel are mostly sourced outside the local economy. However, the Bawinanga Aboriginal Corporation sources all of these from within the community. Furthermore, with outside interests taking control of harvests, the community may lose local ownership of the enterprise and management of wildlife resources. Governments are actively encouraging employment in remote Indigenous communities (NTG, 2009; Closing the Gap: Prime Minister's Report, 2013). Royalties (often termed sit-down money) provide a disincentive for people to participate in the workforce (Pearson, 1999) and can threaten opportunities for Indigenous employment in regions where few such opportunities exist (Altman, 2000).

Royalty payments have become a contentious issue in Maningrida, to the extent that egg harvesting did not take place in 2007-2008 (Table 1; Figs 3a,b \& 4) because a moratorium was placed on egg harvesting by the Northern Land Council. Landowners could not reach a consensus regarding which of three proponents (one of which was the Bawinanga Aboriginal Corporation) would be granted access to crocodile egg resources for commercial purposes. When access was granted the following year, the allocation for the region was divided between the three proponents, and the Corporation (the only local and Indigenous one involved) had its harvest areas and quota reduced. The increased competition for egg resources drove the royalty price up (Table 1 ; Fig. 4), making it harder for the Corporation to compete. During these years the business was paying $50 \%$ of income as royalties (Table 1; Fig. 4), which prevented it from operating in a financially viable manner. This position (i.e. increased royalties to landowners through increased competition between proponents) was promoted by the Northern Land Council officers responsible for facilitating Land Use Agreement negotiations, despite it threatening the viability of an Indigenous-owned and operated enterprise. Whether this is an official policy position that the Council has adopted, or these individuals' interpretation of their mandate under section 19 of the Aboriginal Land
Rights (Northern Territory) Act 1976, is unclear. Either way, the Northern Land Council must revise its role and adopt a more balanced local approach that aims to sustain remote businesses that provide local Indigenous employment as well as other less tangible but equally important capacity-building and self-determination outcomes.

Since its inception in the 1990s the market chain connecting saltwater crocodile eggs in Maningrida to markets for luxury leather items has changed significantly. Both the markets and the supply chains have matured and now require large volumes of skins to be delivered reliably in line with contractual obligations. Commercial operations that buy eggs and hatchlings from the Bawinanga Aboriginal Corporation can no longer afford to base their businesses on a supply of eggs and hatchlings that is highly variable from year to year (Fig. 3). Hence it is understandable why outside operators have taken an active interest in exercising more control over harvests in remote areas, and prefer to conduct their own harvests rather than partner with local businesses. Furthermore, as prices for eggs are driven up by market demand, it is becoming increasingly feasible for crocodile farms to conduct captive-breeding programmes, thus reducing the need for wild-harvested products. This could undermine incentives for conservation of wild crocodiles and their habitats, and any benefits to Indigenous communities.

The lesson for the Bawinanga Aboriginal Corporation, and other similar remote Indigenous businesses, is that to sustain and build the enterprise it must find ways to be a more efficient and dependable supplier, working with rather than in competition with other providers whenever possible, while increasing the benefits local people gain through broader involvement with the industry. Working more closely with the crocodile farming industry could be mutually beneficial, as products derived from programmes that directly benefit Indigenous communities and livelihoods have a special place in the corporate social responsibility platforms of an increasing number of high-end fashion industries.

\section{Conclusion}

The crocodile egg harvesting enterprise in Maningrida is successful relative to many other Indigenous wildlifebased enterprises in Australia (Dale, 1996). It is the only Indigenous-owned and managed harvest in what is largely a non-indigenous dominated industry. Despite this, it has not reached its full potential. The enterprise was not initially profit driven, but rather socially driven. However, it was at that time matched to the embryonic crocodile industry, which itself was only marginally profitable. The highly competitive nature of the crocodile farming industry today has forced farms and other egg harvesters to refine collection and incubation methods to increase productivity and profit 
margins, hence Indigenous egg harvesters will need to be more efficient, or risk being side-lined by non-indigenous harvesters. The Bawinanga Aboriginal Corporation has demonstrated both the capacity and intent to achieve this.

Staff training, to ensure capacity is built and maintained, will increase incubation success rates. Programmes that protect nesting habitat from feral animals will benefit both people and conservation. If participation in the broader mainstream economy is a major government priority for remote communities, then less emphasis needs to be placed on royalties, and more on ensuring Indigenous employment, training and capacity building within the industry. Likewise, the Northern Land Council needs to reduce the bureaucracy for wildlife harvesting enterprises, and give harvesters sufficient freedom to pursue innovative and potentially viable livelihood options (Cooney \& Edwards, 2009). Commercial harvests of crocodile eggs can continue to be sustainable, while providing both conservation benefits and economic opportunities for Indigenous people in remote northern Australia, provided harvests are managed, marketed and supported appropriately.

\section{Acknowledgements}

Many people from the Bawinanga Aboriginal Corporation and Wildlife Management International contributed to the collection of the data presented in this case study, and supported egg harvests in Maningrida; in particular, I. Munro, V. Rostron, M. Ryan, R. Hall, G. Enever, S. Ansell, J. Adjerral (deceased), C. Godjuwa (deceased), D. Yirbarbuk, O. Campion, D. Bond, P. Cooke, B. Ottley and M. Brien. We thank C. Eisemberg, S. Reynolds, R. Cooney and an anonymous reviewer for comments that improved this article.

\section{Author contributions}

BC, AF, BJA and GJW conceived the study; BC, SCM, DN, $\mathrm{YF}$ and $\mathrm{KS}$ compiled the harvest data, and $\mathrm{BC}$ carried out the analyses. All authors contributed to writing the article.

\section{References}

Altman, J.C. (2000) The economic status of Indigenous Australians. CAEPR Discussion Paper No. 193/200o. Centre for Aboriginal Economic Policy Research, Australian National University, Canberra, Australia.

Altman, J.C., Buchanan, G. \& Larsen, L. (2007) The environmental significance of the Indigenous estate: natural resource management as economic development. CAEPR Discussion Paper No. 286/2007. Centre for Aboriginal Economic Policy Research, Australian National University, Canberra, Australia.
Altman, J.C. \& Cochrane, M. (2005) Sustainable development in the Indigenous owned savanna: innovative institutional design for cooperative wildlife management. Wildlife Research, 32, 473-480.

Ansell, S. \& Koenig, J. (2011) CyberTracker: an integral management tool used by rangers in the Djelk Indigenous Protected Area, central Arnhem Land, Australia. Ecological Management and Restoration, $12,13-25$.

Austin, B.J. \& Corey, B. (2012) Factors contributing to the longevity of the commercial use of crocodiles by Indigenous people in remote northern Australia: a case study. The Rangeland Journal, 34, 239-248.

Austin, B.J. \& Garnett, S.T. (2011) Indigenous wildlife enterprise: mustering swamp buffalo (Bubalus bubalis) in Northern Australia. Journal of Enterprising Communities: People and Places in the Global Economy, 5, 309-323.

BidDLE, N., TAYLOR, J. \& YAP, M. (2008) Indigenous participation in regional labour markets, 2001-06. CAEPR Discussion Paper No. 288/2008. Centre for Aboriginal Economic Policy Research, Australian National University, Canberra, Australia.

BrooK, B.W., Bowman, D.M.J.S., Bradshaw, C.J.A., Campbell, B.M. \& WhiteheAD, P.J. (2006) Managing an endangered Asian bovid in an Australian national park: the role and limitations of ecologicaleconomic models in decision-making. Environmental Management, 38, 463-469.

Burgess, C.P., Johnston, F.H., Berry, H.L., McDonnell, J., Yibarbuk, D., Gunabarra, C. et al. (2009) Healthy country, healthy people: the relationship between Indigenous health status and "caring for country". Medical Journal of Australia, 190, 567-572.

CHild, B. (1996) The practice and principles of community-based wildlife management in Zimbabwe: the CAMPFIRE programme. Biodiversity and Conservation, 5, 369-398.

CITES (2017) The CITES Appendices. Http://www.cites.org/eng/app/ index.shtml [accessed 15 February 2017].

Closing the Gap: Prime Minister's Report (2013) Https://www. dss.gov.au/sites/default/files/documents/o2_2013/o0313-ctg-report_ fa1.pdf [accessed January 2017].

Convention on Biological Diversity (2004) Addis Ababa Principles and Guidelines for Sustainable Use of Wild Living Resources. Secretariat of the Convention on Biological Diversity, Montreal, Canada.

Cooney, R. (2008) Commercial and sustainable use of wildlife: suggestions to improve conservation, land management and rural economies. Publication No. 08/199. Rural Industries Research and Development Corporation, Canberra, Australia.

Cooney, R. \& Edwards, M. (2009) Indigenous Wildlife Enterprise Development: The Regulation and Policy Context and Challenges. Report to North Australian Indigenous Land and Sea Management Alliance, Darwin, Australia.

Cooney, R., Kasterine, A., MacMillan, D., Milledge, S., Nossal, K., Roe, D. \& 'T SAs-Rolfes, M. (2015) The Trade in Wildlife: A Framework to Improve Biodiversity and Livelihood Outcomes. International Trade Centre, Geneva, Switzerland.

DALE, A. (1996) Community-based planning in establishing wildlife projects. In Sustainable Use of Wildlife by Aboriginal Peoples and Torres Strait Islanders (eds M. Bomford \& J. Caughley), pp. 110-125. Australian Government Publishing Service, Canberra, Australia.

Davies, J., Higginbottom, K., Noack, D., Ross, H. \& Young, E. (1999) Sustaining Eden: Indigenous Community Wildlife Management in Australia. Evaluating Eden Series, Volume 1. International Institute for Environment and Development, London, UK.

Davies, J., Hill, R., Walsh, F.J., Sandford, M., Smyth, D. \& Holmes, M.C. (2013) Innovation in management plans for 
community conserved areas: experiences from Australian Indigenous Protected Areas. Ecology and Society, 18, 14.

DoB (Department of Business) (2015) Northern Territory Crocodile Farming Industry: Strategic Plan 2015-21. Northern Territory Department of Business, Darwin, Australia.

Eisemberg, C.C., Rose, M., Yaru, B. \& Georges, A. (2011) Demonstrating decline of an iconic species under sustained indigenous harvest-the pig-nosed turtle (Carettochelys insculpta) in Papua New Guinea. Biological Conservation, 144, 2282-2288.

Fordham, A., Fogarty, W. \& Fordham, D. (2010) The viability of wildlife enterprises in remote Indigenous communities of Australia: a case study. CAEPR Working Paper No. 63/2010. Centre for Aboriginal Economic Policy Research, Australian National University, Canberra, Australia.

Fordham, D.A., Georges, A. \& Brook, B.W. (2008) Indigenous harvest, exotic pig predation and local persistence of a long-lived vertebrate: managing a tropical freshwater turtle for sustainability and conservation. Journal of Applied Ecology, 45, 52-62.

Fordham, D.A., Georges, A. \& Corey, B. (2007) Optimal conditions for egg storage, incubation and post-hatching growth for the freshwater turtle, Chelodina rugosa: science in support of an indigenous enterprise. Aquaculture, 270, 105-114.

Fordham, D., Georges, A., Corey, B. \& Brook, B. (2006) Feral pig predation threatens the indigenous harvest and local persistence of snake-necked turtles in northern Australia. Biological Conservation, 133, 379-388.

Fukuda, Y., Manolis, C. \& Appel, K. (2014) Management of human-crocodile conflict in the Northern Territory, Australia: review of crocodile attacks and removal of problem crocodiles. The Journal of Wildlife Management, 78, 1239-1249.

Fukuda, Y., Webi, G., Manolis, C., Delaney, R., Letnic, M., Lindner, G. \& Whitehead, P. (2011) Recovery of saltwater crocodiles following unregulated hunting in tidal rivers of the Northern Territory, Australia. The Journal of Wildlife Management, 75, 1253-1266.

Garnett, S.T., Sithole, B. \& Whitehead, P.J., Burgess, C.P., Johnston, F.H. \& Lea, T. (2009) Healthy country, healthy people: policy implications of links between indigenous human health and environmental condition in tropical Australia. Australian Journal of Public Administration, 68, 53-66.

Gordon, I. \& Ayiemba, W. (2003) Harnessing butterfly

biodiversity for improving livelihoods and forest conservation: the Kipepeo Project. The Journal of Environment and Development, 12, 82-98.

Gorman, J. \& Vemuri, S. (2012) Social implications of bridging the gap through 'caring for country' in remote Indigenous communities of the Northern Territory, Australia. The Rangeland Journal, 34, $63-73$.

Gorman, J.T., Whitehead, P.J., Griffiths, A.D. \& Petheram, L. (2008a) Production from marginal lands: indigenous commercial use of wild animals in Northern Australia. International Journal of Sustainable Development and World Ecology, 15, 240-250.

Gorman, J.T., Pearson, D. \& Whitehead, P. (2008b) Assisting Australian indigenous resource management and sustainable utilization of species through the use of GIS and environmental modelling techniques. Journal of Environmental Management, 86, 104-113.

Hutton, J.M. \& Leader-Williams, N. (2003) Sustainable use and incentive-driven conservation: realigning human and conservation interests. Oryx, 37, 215-226.

IsberG, S., Shilton, C. \& Thomson, P. (2009) Improving Australia's crocodile industry productivity - understanding runtism and survival. Publication No. 09/135. Rural Industries Research and Development Corporation, Canberra, Australia.
IUCN (2004) Implementing the Addis Ababa Principles and Guidelines for the Sustainable Use of Biodiversity. WCC3 Res3.o74. IUCN, Gland, Switzerland.

Koenig, J., Altman, J.C. \& Griffiths, A.D. (2011) Artists as harvesters: natural resource use by Indigenous woodcarvers in central Arnhem Land, Australia. Human Ecology, 39, 407-419.

Leach, G.J., Delaney, R. \& Fukuda, Y. (2009) Management Program for the Saltwater Crocodile in the Northern Territory of Australia: 2009-2014. Northern Territory Department of Natural Resources, Environment, the Arts and Sport, Darwin, Australia.

Lichtenstein, G. (2010) Vicuña conservation and poverty alleviation? Andean communities and international fibre markets. International Journal of the Commons, 4, 100-121.

Lindsey, P.A., Havemann, C.P., Lines, R.M., Price, A.E., Retief, T.A., Rhebergen, T. et al. (2013) Benefits of wildlife-based land uses on private lands in Namibia and limitations affecting their development. Oryx, 47, 41-53.

MARU, Y.T. \& Davies, J. (2011) Supporting cross-cultural brokers is essential for employment among Aboriginal people in remote Australia. The Rangeland Journal, 33, 327-338.

McRae-Williams, E. \& Gerritsen, R. (2010) Mutual incomprehension: the cross-cultural domain of work in a remote Australian Aboriginal community. International Indigenous Policy Journal, $1,2$.

Messel, H., Vorlicek, G.C., Wells, A.G. \& Green, W.J. (1981) Surveys of Tidal River Systems in the Northern Territory of Australia and their Crocodile Populations. Monograph 1. The Blyth-Cadell Rivers System Study and the Status of Crocodylus porosus in Tidal Waterways of Northern Australia. Pergammon Press, Sydney, Australia.

NLC (Northern Land Council) (2011) Northern Land Council Annual Report: 2010-2011. Northern Land Council, Darwin, Australia.

NTG (Northern Territory Government) (2009) Maningrida Study. Department of Regional Development, Primary Industries, Fisheries and Resources, Darwin, Australia.

Pearson, N. (1999) Positive and negative welfare and Australia's Indigenous communities. Family Matters, 54, 30-35.

Robinson, J.G. \& BenNetT, E.L. (2002) Will alleviating poverty solve the bushmeat crisis? Oryx, 36, 332 .

Russell-Smith, J., Сook, G.D., Cooke, P.M., Edwards, A.C., Lendrum, M., Meyer, C.P. \& Whitehead, P.J. (2013) Managing fire regimes in north Australian savannas: applying Aboriginal approaches to contemporary global problems. Frontiers in Ecology and the Environment, 11, e55-e63.

SAALfELd, K. (2014) Feral Buffalo (Bubalus bubalis): Distribution and Abundance in Arnhem Land, Northern Territory. Department of Land Resource Management, Darwin, Australia.

Sodhi, N.S., Koh, L.P., Brook, B.W. \& NG, P.K.L. (2004) Southeast Asian biodiversity: an impending disaster. Trends in Ecology and Evolution, 19, 654-66o.

TAYLOR, J. (2003) Indigenous economic futures in the Northern Territory: the demographic and socioeconomic background. CAEPR Discussion Paper 246/2003. Centre for Aboriginal Economic Policy Research, Australian National University, Canberra, Australia.

W Евв, G.J.W. (2002) Conservation and sustainable use of wildlife - an evolving concept. Pacific Conservation Biology, 8, 12-26.

Wевв, G.J.W. \& Manolis, S.C. (1992) Monitoring saltwater crocodiles (Crocodylus porosus) in the Northern Territory of Australia. In Wildlife 2001: Populations (eds D.R. McCullough \& R. H. Barrett), pp. 404-418. Elsevier Applied Science, New York, USA.

Webb, G.J.W., Manolis, S.C., Dempsey, K.E. \& Whitehead, P.J. (1987) Crocodilian eggs: a functional overview. In Wildlife Management: Crocodiles and Alligators (eds G.J.W. Webb, S. C. Manolis \& P.J. Whitehead), pp. 417-422. Surrey Beatty \& Sons, Sydney, Australia. 
Webi, G.J.W., Messel, H. \& Magnusson, W.E. (1977) The nesting biology of Crocodylus porosus in Arnhem Land, northern Australia. Copeia, 1977, 238-249.

Webb, G., Missi, C. \& Cleary, M. (1996) Sustainable use of crocodiles by Aboriginal people in the Northern Territory. In Sustainable Use of Wildlife by Aboriginal Peoples and Torres Strait Islanders (eds M. Bomford \& J. Caughley), pp. 176-185. Australian Government Publishing Service, Canberra, Australia.

Wilson, G.R., Edwards, M.J. \& Smits, J.K. (2010) Support for Indigenous wildlife management in Australia to enable sustainable use. Wildlife Research, 37, 255-263.

\section{Biographical sketches}

Ben Corey has lived and worked with Aboriginal people in Arnhem Land, on wildlife and land management projects. He currently works on conservation and management of threatened species. GrahAMF WЕв в has been involved in the conservation, management and sustainable use of crocodilians for over 40 years. Charlie Manolis has expertise in the ecology, physiology, zoology and management of crocodiles. Ad R I A N Ford H a m was a Visiting Fellow at the Centre for Aboriginal Economic Policy Research, Australian National University, during this study, specializing in the development, implementation and evaluation of education, training and employment programmes for Indigenous peoples in remote regions. BEAU AUSTIN is working on measures of effectiveness in Indigenous land and sea management. YUSUKE FUKUDA's work focuses on wild populations of crocodiles in Australia. Dominic Nicholls is the Chief Executive Officer of the Mimal Land Management Aboriginal Corporation, and was previously the manager of the Bawinanga Aboriginal Corporation Djelk Rangers in Maningrida. Keith SAALfeld works on the conservation of saltwater crocodiles and other wildlife management programmes. 